\title{
Determination of Rain Intensity Based on Rain Characteristics Observed from Rain Observation Stations Around South Jakarta
}

\author{
Pavita Khansa $^{1}$, Evi Siti Sofiyah ${ }^{1}$, and I Wayan Koko Suryawan ${ }^{1 *}$ \\ ${ }^{1}$ Faculty of Infrastructure Planning, Department of Environmental Engineering, Universitas Pertamina, \\ Jakarta 12220, Indonesia \\ *Corresponding author: iwayankokosuryawan@gmail.com
}

(Received: June $17^{\text {th }}, 2020$; Revised: October $1^{\text {st }} 2020$; Accepted: October $14^{\text {th }} 2020$ )

\begin{abstract}
South Jakarta has the highest rainfall concentration and the most flood location in Jakarta. Therefore, an urban drainage system is needed to control surface water so flood can be prevented. This research aims to support the urban drainage system planning by determining rainfall intensity based on three methods, those are Van Breen, Bell Tanimoto, and Hasper der Weduwen. The most suitable method will be selected by comparing the value of rainfall intensity with Talbot, Sherman, and Ishiguro approach. This research reveals that the most suitable method is the Van Breen Method with the Talbot equation. The result of the calculation is rainfall intensity for $2,5,10,25,50$, and 100 years rain return period, with each range $27.2-182.8 \mathrm{~mm} /$ hour, 36.8-197.6 mm/hour, 43.1-206.3 mm/hour, 51.1-216.6 mm/hour, 57-223.9 $\mathrm{mm} /$ hour, and 63-230,8 $\mathrm{mm} /$ hour.
\end{abstract}

Keywords: rainfall; intensity; drainage

\section{Introduction}

Flood has been an endless problem for people all around the world from the past, present, and future [1-3]. In Indonesia, even though the timing and magnitude of floods vary, almost all regions face significant flooding hazards [4-7]. The flooding phenomenon and land subsidence are a natural phenomenon in Jakarta that continuously occurs, causing various damages and losses, and requires serious treatment [8]. South Jakarta is an area that has the most flood locations [9-11].

Lestanto and Paski analysis, shows that the overall rainfall data in South Jakarta has the highest underestimate chance [12]. According to Prabawadhani et al also showed that the highest rainfall concentrations tend to occur in the central to southern areas of DKI (Special Capital District) Jakarta Province, especially around the borders between DKI Jakarta (South Jakarta), West Java (Depok), and Banten (South Tangerang) [13]. Urban drainage is drainage in urban areas that functions to control surface water so that it does not harm the public. It can be done by planning a good drainage system by considering the hydrological conditions of the area.

In planning the drainage system, determining the value of rainfall intensity is needed to get the value of the flood discharge in the planning area. Rain intensity value will determine the quantity of rain per unit time. The length time of rain duration will be inversely proportional to the magnitude of the rainfall intensity. The shorter the duration is, the greater its intensity and return period. By knowing the intensity of occurred rain, is expected to be used as a basis for planning drainage channel capacity 'in the return period. One approach that can be done to determine the 
rainfall intensity is by calculating using Van Breen method, Bell Tanimoto method, and Hasper der Weduwen method.

This research aims to determine the rainfall intensity calculated based on three methods, those are the Van Breen, Bell Tanimoto, and Hasper der Weduwen. Derivation value is determined by comparing the value of rainfall intensity with Talbot, Sherman, and Ishiguro approach.

\section{Methods}

This research is conducted by adapting SNI 2415-2016 on the procedure for calculating flood discharge plans [14]. Starting by observing South Jakarta's geographic condition and obtaining annual maximum daily rainfall data for the last 25 years from observation stations located around South Jakarta. Then, the data from various stations are processed to get the mean values from each year. After that, the homogeneity test is applied to the mean values. Following the test is maximum daily rainfall analysis using 3 methods, such as the Gumbel method, Log Pearson Type II method and Normal distribution method. Among these three methods, only one will be used to determine rainfall intensity, which selected based on the Chi-Square compatibility test. Rainfall intensity analysis is conducted with the Van Breen method, Bell Tanimoto method, and Hasper der Weduwen method. One of the equations will be selected to create Intensity-DurationFrequency Curve. The chosen equation is decided through comparing the gaps made by testing each equation with the Talbot, Sherman and Ishiguro equations.

\section{Result and Discussion}

\subsection{Data of Annual Average Rainfall in Nearby Stations}

Rainfall in South Jakarta is the amount of rainwater that falls in South Jakarta within a certain time. The rainfall data used is the maximum daily rainfall data for the last 25 years from three rain observation stations around South Jakarta. Rainfall data can be seen in Table 1. According to Prabhawadani et al., mentioned that the rain occurred in DKI Jakarta tends to accumulate a lot in the central to southern Jakarta [13].

Table 1. Annual Average Rainfall Data in Rain Observation Stations Wilayah Around South Jakarta

\begin{tabular}{ccccc}
\hline no & Year & $\begin{array}{c}\text { Klimatologi } \\
\text { Tangerang Selatan } \\
(\mathbf{m m})\end{array}$ & $\begin{array}{c}\text { Meteorologi } \\
\text { Kemayoran }(\mathbf{m m})\end{array}$ & $\begin{array}{c}\text { Halim Perdana } \\
\text { Kusuma Jakarta } \\
(\mathbf{m m})\end{array}$ \\
\hline 1 & 1995 & 113.30 & 48.30 & 295.10 \\
\hline 2 & 1996 & 113.83 & 137.94 & 150.78 \\
\hline 3 & 1997 & 82.62 & 80.13 & 161.55 \\
\hline 4 & 1998 & 108.55 & 103.48 & 90.47 \\
\hline 5 & 1999 & 97.57 & 93.91 & 90.47 \\
\hline 6 & 2000 & 103.40 & 94.80 & 58.67 \\
\hline 7 & 2001 & 104.00 & 82.20 & 100.27 \\
\hline 8 & 2002 & 109.20 & 168.50 & 116.26 \\
\hline 9 & 2003 & 119.20 & 119.19 & 162.74 \\
\hline 10 & 2004 & 94.00 & 168.56 & 102.36 \\
\hline 11 & 2005 & 104.50 & 161.78 & 93.77 \\
\hline 12 & 2006 & 79.30 & 93.86 & 230.57 \\
\hline 13 & 2007 & 272.05 & 305.96 & 144.21 \\
\hline 14 & 2008 & 167.33 & 251.21 & 148.77 \\
\hline 15 & 2009 & 91.27 & 159.69 & \\
\hline
\end{tabular}




\begin{tabular}{ccccc}
\hline 16 & 2010 & 60.85 & 121.24 & 26.83 \\
\hline 17 & 2011 & 93.57 & 155.39 & 84.53 \\
\hline 18 & 2012 & 120.63 & 87.15 & 94.40 \\
\hline 19 & 2013 & 145.12 & 160.22 & 161.00 \\
\hline 20 & 2014 & 180.64 & 122.53 & 120.80 \\
\hline 21 & 2015 & 176.86 & 229.89 & 124.60 \\
\hline 22 & 2016 & 146.63 & 103.14 & 111.60 \\
\hline 23 & 2017 & 121.23 & 148.87 & 136.30 \\
\hline 24 & 2018 & 130.45 & 86.65 & 101.20 \\
\hline 25 & 2019 & 117.00 & 74.97 & 72.65 \\
\hline
\end{tabular}

Figure 1 shows the AMDR chart from 1995 to 2019. The AMDR mean in South Jakarta shows a value of $126.4 \mathrm{~mm}$. According to Syafei and Hidayati, the five categories are rainfall with a range of $<100 \mathrm{~mm}$ (low), 100-200 mm (slightly low), 200-300 mm (moderate), 300-400 mm (slightly high), and $>400 \mathrm{~mm}$ (high) [15]. Overall rainfall in South Jakarta is considered as the medium category.

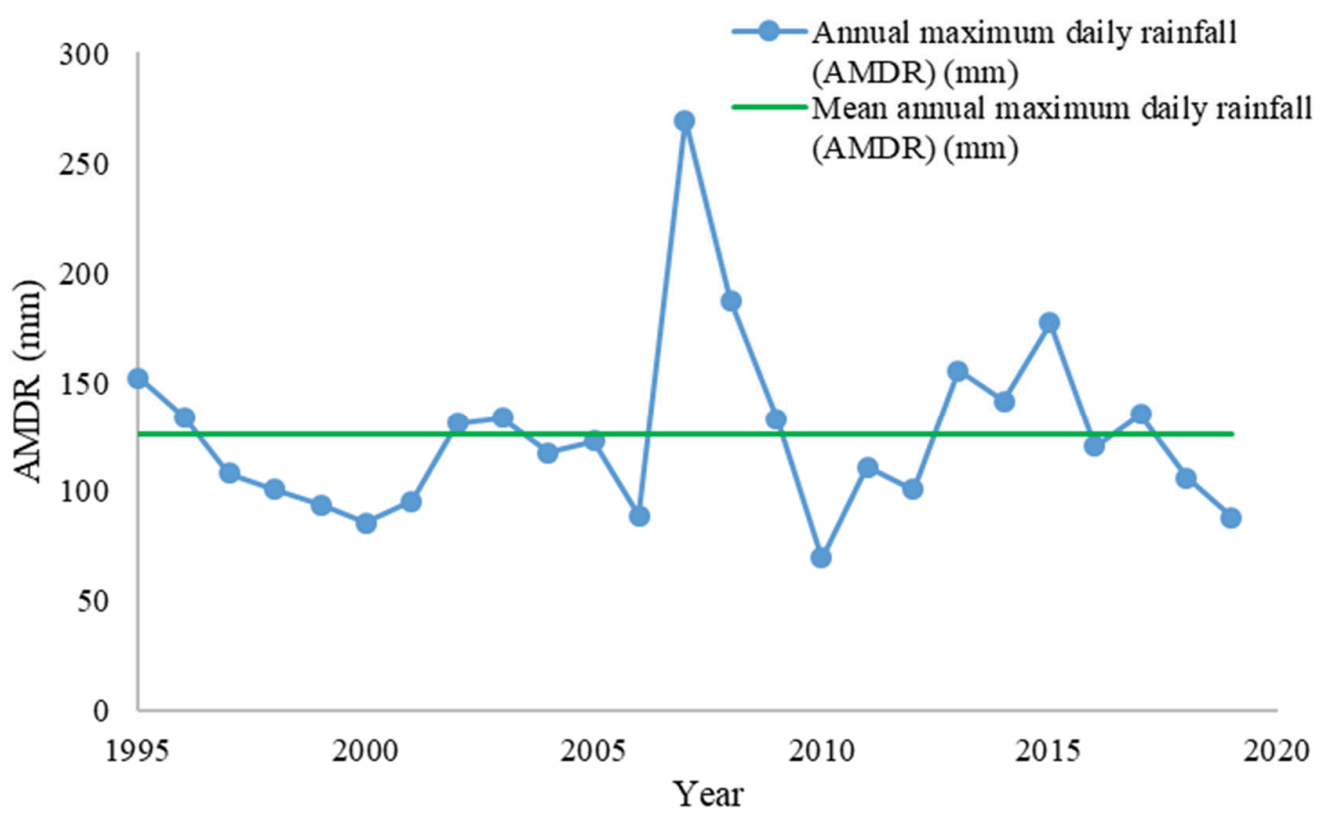

Fig. 1. Annual Maximum Daily Rainfall Data in South Jakarta

\subsection{Homogeneity Test}

The purpose is to test whether the maximum rainfall occurs homogeneously in the entire study area. If it is not homogeneous, the researchers need to find a homogeneous data set. To determine homogeneity, it is necessary to calculate the TR value from the $\mathrm{x}$ equation. Calculation results can be seen in Table 2 .

Table 2. TR Calculation Results for Annual Maximum Daily Rainfall Homogeneity Test in South Jakarta

\begin{tabular}{lc}
\hline \multicolumn{1}{c}{ Stages of Homogeneity Calculation } & Result \\
\hline Total (Ri-R) & (20967.97 \\
\hline Reduce Standard Deviation $(\mathrm{Sn})$ & 1.09 \\
\hline Reduced Mean $(\mathrm{Yn})$ & 0.53 \\
\hline
\end{tabular}




\begin{tabular}{lc}
\hline Standard Deviation & 41.32 \\
\hline $1 / \alpha$ & 37.85 \\
\hline$\mu$ & 106.34 \\
\hline Gumbell Regression Equation & $106.3429+37.853 x$ \\
\hline $\mathrm{Y} 0$ & 106.34 \\
\hline $\mathrm{Y} 5$ & 295.60 \\
\hline $\mathrm{Y} 1$ & 144.20 \\
\hline $\mathrm{Tr}$ & 1.12 \\
\hline $\mathrm{R}_{10}$ & 345.00 \\
\hline $\mathrm{TR}$ & 3.06 \\
\hline
\end{tabular}

Test results show that the data from three rain stations in South Jakarta are homogeneous. From the calculation, value $(\mathrm{N}: \mathrm{TR})=(25: 3)$ obtained, it turns out that the point is within the region of homogeneity limit (Figure 2), so the data is 25 years homogeneous.

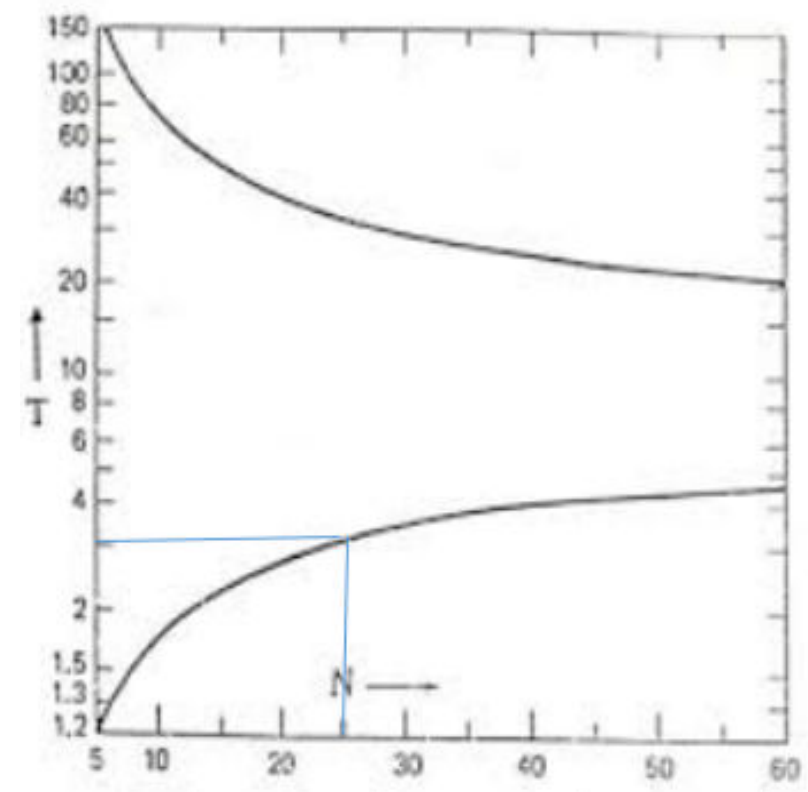

Fig. 2. Homogeneity of 25 Years of Rainfall Maximum Daily Rainfall in South Jakarta Region

\subsection{Maximum Daily Rainfall Analysis}

The maximum daily rainfall that will occur during a certain return period can be estimated by several methods such as the Gumbel method, Log Pearson Type II method and Normal distribution method. The purpose of this analysis is to obtain a regression line, which is a place of maximum rainfall value. The calculation results of this method can be seen in Table 3, Table 4, and Table 5.

Table 3. Results of Maximum Daily Rainfall Analysis with the Gumbell Method

\begin{tabular}{cccc}
\hline Rain Return Periods (Tr) & Yt & K & Xt (mm/day) \\
\hline 2 & 0.37 & -0.15 & 120.34 \\
\hline 5 & 1.50 & 0.89 & 162.38 \\
\hline 10 & 2.25 & 1.58 & 190.21 \\
\hline 15 & 2.67 & 1.96 & 205.91 \\
\hline
\end{tabular}




\begin{tabular}{cccc}
\hline 25 & 3.199 & 2.44 & 225.37 \\
\hline 50 & 3.90 & 3.09 & 251.46 \\
\hline 100 & 4.60 & 3.73 & 277.36 \\
\hline
\end{tabular}

Table 4. Results of Calculation of Maximum Daily Rainfall Analysis with Pearson II Log Method

\begin{tabular}{cccc}
\hline Rain Return Periods & K & log RT & Maximum rainfall \\
\hline 2 & -0.11 & 2.07 & 117.25 \\
\hline 5 & 0.79 & 2.18 & 152.35 \\
\hline 10 & 1.33 & 2.25 & 178.13 \\
\hline 25 & 1.96 & 2.33 & 213.74 \\
\hline 50 & 2.40 & 2.38 & 242.50 \\
\hline 100 & 2.81 & 2.44 & 273.29 \\
\hline
\end{tabular}

Table 5. Results of Calculation of Maximum Daily Rainfall Analysis with the Normal Distribution Method

\begin{tabular}{ccc}
\hline $\mathbf{T}$ & $\mathbf{K t}$ & $\mathbf{X t}$ (Rain Return Periods) \\
\hline 2 & 0.00 & 126.44 \\
\hline 5 & 0.84 & 160.44 \\
\hline 10 & 1.28 & 178.25 \\
\hline 25 & 1.71 & 195.58 \\
\hline 50 & 2.05 & 209.42 \\
\hline 100 & 2.33 & 220.76 \\
\hline
\end{tabular}

The selecting method of the maximum daily rainfall calculating is intended to choose the most appropriate method for estimating the amount of maximum daily rainfall that occurs in a particular Rain Return Periods. The results obtained from the three methods used. In selecting the analysis method of maximum daily rainfall, the Test of Goodness of fit frequency distribution from the data to the probability distribution function that expected to be able to represent the frequency, distribution is required. Parameter testing can be done with a compatibility test, ChiSquare. To conduct this compatibility test, the maximum daily rainfall will be compared based on the methods used. Chi-Square Test intended to determine whether the equation or method chosen could represent the statistical distribution of the sample of the analyzed data.

The results show that the Gumbel method provides this criterion. The Gumbel distribution has a coefficient of Skwennes or Cs $\approx 1,14$ and a coefficient of kurtosis (Coefficient Kurtosis) or $\mathrm{Ck} \approx 5,40$, this method usually uses distributions and extreme values with exponential double distribution [16].

\section{The Determination of Rain Intensity}

The final stage of rainfall analysis is the analysis in the form of Intensity Duration Frequency (IDF), which shows the relationship between the drainage length time and the rain intensity, for each rain return period. If data for each rain duration is unknown, then an empirical approach needed to refer to the duration of 60 minutes ( 1 hour) and the maximum daily rainfall that occurs each year. Another common way is a pattern taking of rainfall intensity in other cities that have similar conditions. The methods used are Der Weduwen Hasper Method and Van Breen Method.

Based on the calculation of rainfall intensity, it appears that the highest / largest rainfall intensity value. The greatest value of rainfall intensity is used in determining the dimensions of drainage 
channels, where the channel should be able to accommodate rainfall with maximum intensity. The amount of rainfall intensity varies due to the length of rainfall duration or the frequency of occurrence. For this reason, the selected rainfall intensity was tested with Talbot, Sherman and Ishiguro equations and then compared. This comparison will form the error gap, the results of error calculation for each method can be seen in Table 6 . The chosen method in determining the rainfall intensity is Van Breen by comparison with the Talbot equation.

a. Van Breen method

The following equation is derived from rainfall intensity analysis in Java Island to be more suiteble for Jakarta.

$$
I_{T}=\frac{54 R_{T}+0.07 R_{T}^{2}}{t_{c}+0.3 R_{T}}
$$

Where,

$I_{T} \quad$ : Rainfall intensity at rain return period year $\mathrm{T}(\mathrm{mm} / \mathrm{hour})$

$R_{T}$ : Maximum daily rainfall at rain return period year $\mathrm{T}(\mathrm{mm} /$ day $)$

b. Bell Tanimoto method

The rainfall intensity can be calculate using Bell Tanimoto equation as follows.

$$
\begin{gathered}
R_{T}^{t}=(0.21 \ln T+0.52)\left(0.54 t^{0.25}-0.5\right) R_{10 \text { tahun }}^{60 \text { tahun }} \\
R_{10 \text { tahun }}^{60 \text { menit }}=\frac{X_{10}}{X_{t}}\left(\frac{R_{1}+R_{2}}{2}\right) \\
I_{T}^{t}=\frac{60}{t} R_{T}^{t}
\end{gathered}
$$

Where,

$R \quad:$ Maximum daily rainfall $(\mathrm{mm})$

$T \quad$ : Return period year $\mathrm{T}$ (year)

$t \quad$ : Rainfall duration (minute)

$R_{l} \quad$ : Maximum daily rainfall on first hour $(\mathrm{mm})$

$R_{2} \quad$ : Maximum daily rainfall on second hour $(\mathrm{mm})$

c. Hasper der Weduwen method

The rainfall intensity can be calculate using Hasper der Weduwen equation as follows.

$$
R_{i}=X_{t}\left(\frac{1218}{X_{t}(1-t)+1272 t}\right)
$$

If $1 \leq t<24$ hours, then,

$$
R=\sqrt{\frac{11300 t}{t+3.12}}\left[\frac{R_{i}}{100}\right]
$$

If $0 \leq t<1$ hour, then,

$$
R=\sqrt{\frac{11300}{t+3.12}}\left[\frac{R_{i}}{100}\right]
$$

The rainfall intensity itself is calculated using equation as follows.

$$
I=\frac{R}{t}
$$

Where,

$t \quad$ : Rainfall duration (hour)

$X_{t} \quad$ : Maximum daily rainfall $(\mathrm{mm})$ 
Most suitable mathod to calculate rainfall intensity is selected with 3 equations, such as Talbot, Sherman and Ishiguro equations which are influenced by several factors. Those factors are rainfall intensity, rainfall duration in hours, and the amount of data, with each symbolized as I, t, and N.

a. Talbot equation

$$
\begin{gathered}
I=\frac{a}{t+b} \\
a=\frac{\sum I t \sum I^{2}-\sum\left(I^{2} t\right) \sum I}{N \sum I^{2}-\left(\sum I\right)^{2}} \\
b=\frac{\sum I t \sum I-\sum\left(I^{2} t\right) N}{N \sum I^{2}-\left(\sum I\right)^{2}}
\end{gathered}
$$

b. Sherman equation

$$
\begin{gathered}
I=\frac{a}{t^{n}} \\
\log a=\frac{\sum \log I \sum(\log t)^{2}-\sum(\log t \log I) \sum \log t}{N \sum(\log t)^{2}-\left(\sum \log t\right)^{2}} \\
n=\frac{\sum \log I \sum \log t-\sum(\log t \log I) N}{N \sum(\log t)^{2}-\left(\sum \log t\right)^{2}}
\end{gathered}
$$

c. Ishiguro equation

$$
\begin{gathered}
I=\frac{a}{\sqrt{t}+b} \\
a=\frac{\sum(I \sqrt{t}) \sum I^{2}-\sum\left(I^{2} \sqrt{t}\right) \sum I}{N \sum I^{2}-\left(\sum I\right)^{2}} \\
b=\frac{\sum I \sqrt{t} \sum I-\sum\left(I^{2} \sqrt{t}\right) N}{N \sum I^{2}-\left(\sum I\right)^{2}}
\end{gathered}
$$

Where,

$I \quad:$ Rainfall intensity ( $\mathrm{mm} / \mathrm{hour})$

$t \quad$ : Rainfall duration (minute)

$N \quad$ : amount of data

In Figure 3 can be seen the calculation results or intensity-duration-frequency (IDF) curve plot. This IDF curve will show the relationship between rainfall intensity and the length of rain duration

\begin{tabular}{|c|c|c|c|c|c|c|c|c|c|}
\hline \multirow{2}{*}{$\begin{array}{c}\text { Rain } \\
\text { Return } \\
\text { Peri- } \\
\text { ods }\end{array}$} & \multicolumn{3}{|c|}{ Van Breen } & \multicolumn{3}{|c|}{ Bell Tanimoto } & \multicolumn{3}{|c|}{ Hasper der Weduwen } \\
\hline & $\begin{array}{l}\text { Tal- } \\
\text { bot }\end{array}$ & $\begin{array}{c}\text { Sher- } \\
\text { man }\end{array}$ & Ishiguro & Talbot & Sherman & Ishiguro & Talbot & Sherman & Ishiguro \\
\hline 2 & 0.000 & 9.983 & 10.864 & 2.536 & 1.510 & 38.682 & 11.634 & 6.573 & 118.745 \\
\hline 5 & 0.000 & 11.611 & 11.221 & 4.411 & 2.627 & 84.470 & 15.346 & 6.230 & 291.400 \\
\hline 10 & 0.000 & 12.457 & 11.344 & 6.044 & 3.599 & 62.614 & 17.684 & 5.861 & 138.992 \\
\hline 25 & 0.000 & 13.344 & 11.428 & 8.534 & 5.083 & 79.333 & 20.517 & 5.587 & 147.283 \\
\hline 50 & 0000 & 13.902 & 11.456 & 10.681 & 6.361 & 94.458 & 22.541 & 6.156 & 152.552 \\
\hline 100 & 0.000 & 14.389 & 11.465 & 13.059 & 7.778 & 560.949 & 24.493 & 6.610 & 157.842 \\
\hline
\end{tabular}
[17]. According to Narulita, and Marganingrum, the IDF curve is a tool that can be used to calculate flood discharge plans that needed for the planning of flood control building [18]. In planning the drainage system in an effective flood risk mitigation effort in Jakarta, the duration of the design storm is more than 1 day [19]. The need for a combination of flood control infrastructure can reduce the risk of flood disasters [20]; this importance of plan discharge in the design.

Table 6. Result of Average Error for Each Calculation Method of Van Breen, Bell Tanimoto and Hasper der Weduwen 
Based on gap comparison in Table 6, Van Breen method with Talbot equation is the most suitable to determine South Jakarta's rainfall intensity. Therefore, the result of these calculation, which can be seen in Table 7, will be used to generate IDF curve.

Table 7. Result of Method of Van Breen with Talbot Equation Calculation

\begin{tabular}{ccccccc}
\hline Rain Return Periods & $\mathbf{2}$ & $\mathbf{5}$ & $\mathbf{1 0}$ & $\mathbf{2 5}$ & $\mathbf{5 0}$ & $\mathbf{1 0 0}$ \\
\hline Duration (minute) & \multicolumn{5}{c}{$\mathbf{I}(\mathbf{m m} / \mathbf{h o u r})$} \\
\hline 5 & 182.768 & 197.606 & 206.305 & 216.572 & 223.839 & 230.845 \\
\hline 10 & 162.946 & 180.778 & 190.924 & 202.620 & 210.739 & 218.462 \\
\hline 20 & 133.901 & 154.469 & 166.149 & 179.493 & 188.658 & 197.294 \\
\hline 40 & 98.712 & 119.645 & 131.913 & 146.134 & 155.973 & 165.268 \\
\hline 60 & 78.169 & 97.634 & 109.376 & 123.231 & 132.941 & 142.187 \\
\hline 80 & 64.703 & 82.463 & 93.416 & 106.534 & 115.835 & 124.763 \\
\hline 100 & 55.195 & 71.373 & 81.521 & 93.822 & 102.630 & 111.143 \\
\hline 120 & 48.124 & 62.912 & 72.313 & 83.821 & 92.128 & 100.204 \\
\hline 140 & 42.658 & 56.244 & 64.974 & 75.746 & 83.575 & 91.226 \\
\hline 160 & 38.308 & 50.855 & 58.987 & 69.090 & 76.476 & 83.724 \\
\hline 180 & 34.762 & 46.408 & 54.011 & 63.510 & 70.488 & 77.362 \\
\hline 200 & 31.818 & 42.676 & 49.808 & 58.763 & 65.370 & 71.899 \\
\hline 220 & 29.333 & 39.500 & 46.213 & 54.677 & 60.944 & 67.156 \\
\hline 240 & 27.208 & 36.763 & 43.102 & 51.122 & 57.080 & 63.000 \\
\hline
\end{tabular}

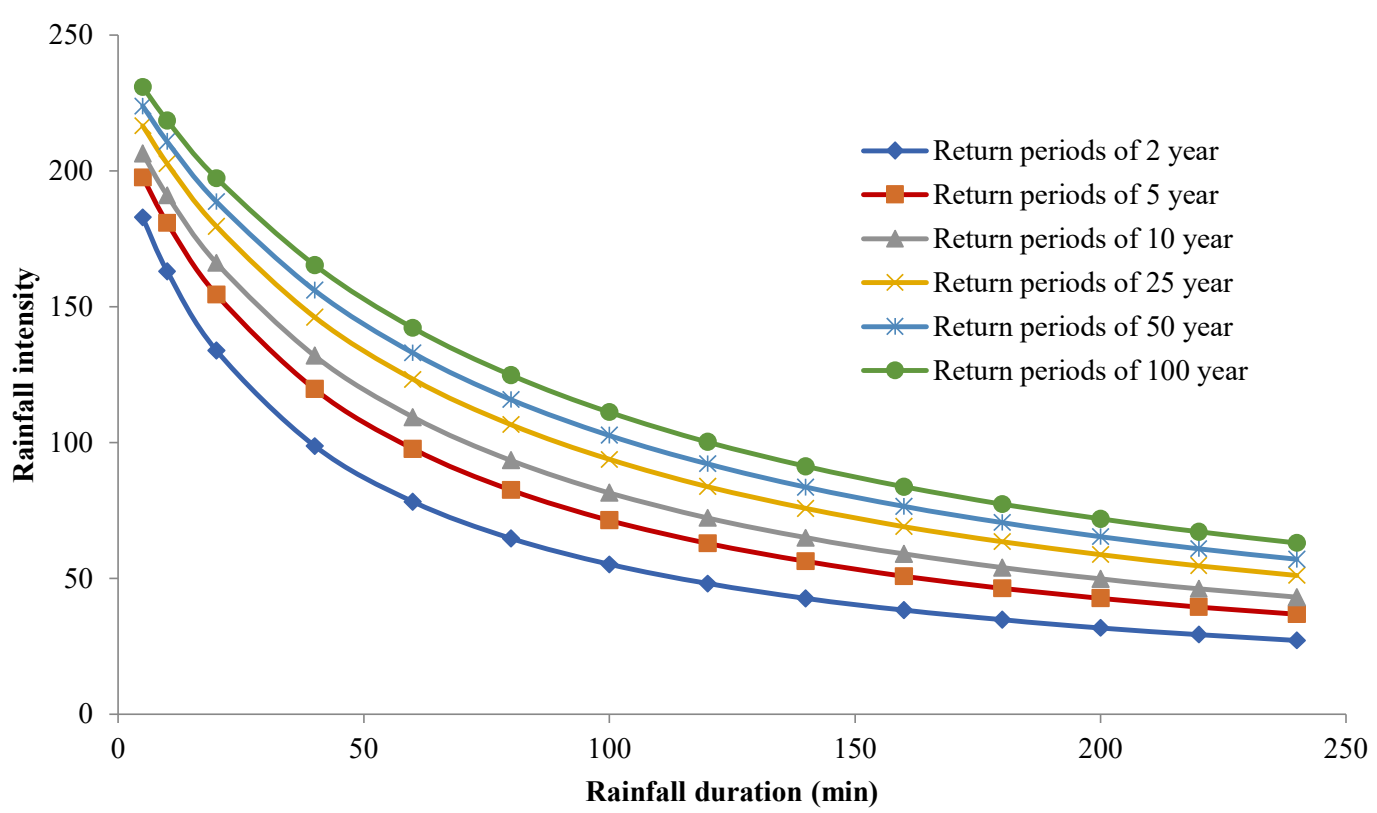

Fig. 3. IDF graph with Van Breen and Talbot equations

In designing drainage infrastructure, the use of return periods is very important to get the urgency of the channel. In macro drainage, an infrastructure design of water resource is applied in the return period of 20-50 years, then for the application techniques of artificial impregnation will be using the same return period [21]. According to Masduki, 1988 for micro drainage channels such 
as Housing, Parks, Non-built land, tertiary channels, and secondary channels can use the return period of 2 to 5 years [22].

The use of a 100-year return period is recommended for the design of macro floods and watersheds with an area of 1300-6500 ha (Masduki, 1988). An example that has happened is the Ciliwung watershed that reached $142.5 \mathrm{~mm}$ /day on 2 February 2007, which was repeated about once 100 years [23]. The rain occurrence of which caused flooding in DKI Jakarta in 2013 and 2014, the rain that caused flooding in 2014 is still in the stage of a 2 years return period, while the 2013 flood event is still in the category of annual planned rain [24].

\section{Conclusion}

Based on rainfall intensity analysis, the Van Breen Method with Talbot equation is the most suitable method to determine South Jakarta's Rainfall and it will be used to create IDF curve. The result of this calculation is rainfall intensity for 2, 5, 10, 25, 50, and 100 years rain return period, with each range $27.2-182.8 \mathrm{~mm} /$ hour, 36.8-197.6 mm/hour, 43.1-206.3 mm/hour, 51.1-216.6 $\mathrm{mm} /$ hour, $57-223.9 \mathrm{~mm} /$ hour, and 63-230.8 $\mathrm{mm} /$ hour.

\section{References}

[1] Cirella, G. T., \& Iyalomhe, F. O. (2018). Flooding conceptual review: Sustainabilityfocalized best practices in Nigeria. Applied Sciences, 8(9), 1558.

[2] Gleick, P. H. (2003). Global freshwater resources: soft-path solutions for the 21 st century. Science, 302(5650), 1524-1528.

[3] van Popering-Verkerk, J., \& van Buuren, A. (2017). Developing collaborative capacity in pilot projects: Lessons from three Dutch flood risk management experiments. Journal of Cleaner Production, 169, 225-233.

[4] Barkey, R., Nursaputra, M., Mappiase, M. F., Achmad, M., Solle, M., \& Dassir, M. (2019, February). Climate change impacts related flood hazard to communities around Bantimurung Bulusaraung National Park, Indonesia. In IOP Conference Series: Earth and Environmental Science (Vol. 235, No. 1, p. 012022). IOP Publishing.

[5] Hadihardaja, I. K., \& Vadiya, R. (2016). Identification of flash flood hazard zones in mountainous small watershed of Aceh Besar Regency, Aceh Province, Indonesia. The Egyptian Journal of Remote Sensing and Space Science, 19(1), 143-160.

[6] Kusmiyarti, T. B., Wiguna, P. P. K., \& Dewi, N. R. (2018, February). Flood Risk Analysis in Denpasar City, Bali, Indonesia. In IOP Conference Series: Earth and Environmental Science (Vol. 123, No. 1, p. 012012). IOP Publishing.

[7] Hartanto, I. S., \& Rachmawati, R. (2017). Assessing the Spatial-Temporal Land use Change and Encroachment Activities Due to Flood Hazard in North Coast of Central Java, Indonesia. The Indonesian Journal of Geography, 49(2), 55-66.

[8] Yuhanafia, N., \& Andreas, H. (2017). Increase of the Estimation between the Economic Loss due to Flood and the Effect of Land Subsidence in Jakarta. Journal of Geografi Gea, 17(2), 182-190. (in Indonesian)

[9] Margatama, L., Al-Hikmah, S. S., Riyanto, I., Pebrianti, D., Bayuaji, L., Sudiana, D., \& Sumantyo, J. T. S. (2018, April). Increasing disaster awareness of the community by flood potential mapping of densely populated urban river watershed in south and west jakarta with LIDAR data segmentation. In 2018 IEEE International Conference on Applied System Invention (ICASI) (pp. 370-373). IEEE.

[10] Marko, K., Kusratmoko, E., Tambunan, M. P., \& Pahlevi, R. (2019, November). A Spatial Approach in Assessing Flood Losses in Floodplain Area of Pesanggrahan River (Case Study on Ulujami and Cipulir Urban Villages, South Jakarta). In IOP Conference Series: Earth and Environmental Science (Vol. 338, No. 1, p. 012030). IOP Publishing.

[11] Utami, I., \& Marzuki, M. (2020). Analysis of Twitter-Based Flood Information System. Journal of Fisika, Unand, 9(1), 67-72. (in Indonesian) 
[12] Lestanto, A. W., \& Paski, J. A. I. (2018). WRF Performance Test using Radar, Satellite and Synoptic Assimilation Data for Rain Prediction in Jakarta. Journal of Sains \& Teknologi Modifikasi Cuaca, 19(1), 1-10. (in Indonesian)

[13] Prabawadhani, D. R., Harsoyo, B., Seto, T. H., \& Prayoga, B. R. (2016). Temporal and Spatial Characteristics of Rainfall causing Flooding in Jakarta and its Surrounding Areas. Journal of Sains \& Teknologi Modifikasi Cuaca, 17(1), 21-25. (in Indonesian)

[14] SNI 2415:2016. Indonesian National Standard. Procedure for Calculating the Planned Flood Discharge. (in Indonesian)

[15] Syafei, M., \& Hidayati, R. (2018). Effect of the Altitude and Rainfall on Diarrhea (A Case Study: Bogor Regency). Journal of Agromet Indonesia, 28(1). (in Indonesian)

[16] Fahliananta, R. (2019). Study of Drainage Channel System Calculation on Jl. Haji Isa III, Tanjung Redeb District, Berau Regency. Student Journal of Kurva S, 1(1), 1709-1716. (in Indonesian)

[17] Permatasari, M., Nugraha, M. C., \& Hartati, E. (2019). Determination of the Rain Intensity Method based on the Rain Characteristics from the Rain Observation Stations around the District of East Karawang. Journal of Serambi Engineering, 5(1). (in Indonesian)

[18] Narulita, I., \& Marganingrum, D. (2017). Analysis of Rainfall, Land Cover Change and IDF Curve Arrangement for Flood Potential Analysis: A Case Study of Cerucuk Watershed, Belitung Island. Journal of Lingkungan dan Bencana Geologi, 8(2). (in Indonesian)

[19] Liu, J., Doan, C. D., Liong, S. Y., Sanders, R., Dao, A. T., \& Fewtrell, T. (2015). Regional frequency analysis of extreme rainfall events in Jakarta. Natural Hazards, 75(2), 10751104.

[20] Januriyadi, N. F., Yulizar, Y., Pamungkas, R. C., Amru, F., \& Fadhilah, N. (2019). Effectiveness of the Infiltration Wells in reducing the Risk of Flood Disaster in the City of Jakarta. (in Indonesian)

[21] Pradiko, H., Sabar, A., Soewondo, P., Suryadi, Y., \& Jatikusuma, I. (2017). IndividualScale Environmental Drainage Model in Settlement Areas in the North Bandung. Journal of Civil Engineering, 24(1), 83-90. (in Indonesian)

[22] Masduki H.S. 1998. Drainage System Planning. Bandung: Institut Teknologi Bandung. (in Indonesian)

[23] Nugroho, S. P. (2018). Analysis of Rainfall causing Large Floods in Jakarta in the Early February 2007. Journal of Air Indonesia, 4(1). (in Indonesian)

[24] Ginting, S., Farid, M., \& Kusuma, S. B. (2015). Development of a Flood Hazard Map based on a Quasi-Mathematical Model of 2 Dimensions. Journal of Civil Engineering, 22(3), 219234. (in Indonesian) 